\title{
Bladder Clear Cell Adenocarcinoma
}

National Cancer Institute

\section{Source}

National Cancer Institute. Bladder Clear Cell Adenocarcinoma. NCI Thesaurus. Code C6179.

A rare morphologic variant of bladder adenocarcinoma characterized by the presence of malignant glandular epithelial cells and clear cells distributed in a tubulo-cystic, papillary, or diffuse pattern. There is a female predilection. Clinical presentation includes hematuria and dysuria. 